\title{
CARACTERISTICA HIBRIZILOR INTERSPECIFICI DE GRÂU DURUM DE TOAMNĂ
}

Rotari Silvia, Leatamborg Svetlana, Gore Andrei

Institutul de Genetică, Fiziologie și Protecție a Plantelor, Chișinău, Republica Moldova

e-mail: silvia.rotari@igfpp.md

\begin{abstract}
In the result of our investigations, in 2016-2019, were obtained 220 hybrids of winter durum wheat with a percentaje of grain biding from 0 to $82.5 \%$ for interspecific hybrids. In interspecific hybrids from the first generation $\left(\mathrm{F}_{1}\right)$, the complete domination is revealed only after the pubescence of the ear and the lack of awns. The color of the ear, the awns and the grains are inherited according to the intermediate type. Interspecific hybrids of $\mathrm{F}_{2}$ and subsequent descendants are characterized by a vigorous process of segregation with the appearance of durum and aestivum wheat with valuble agronomic indices.
\end{abstract}

Key words: Winter durum wheat, triticum aestivum, interspecific hybridization, intraspecific hybridization, variability.

\section{Introducere}

Grâul durum de toamnă este o cultură comparativ nouă, a cărui zămislire nu este un miracol al naturii, ca atâtea altele, ci a fost creat în mod atrificial prin unirea garniturilor cromozomiale a două specii diferite de grâu-Triticum durum și Triticum aestivum.

S-a impus ca o cultură valoroasă, evidențiindu-se în mod deosebit prin însușiri de calitate. Având boabe de o sticlozitate înaltă, cu un conținut sporit de proteină și gluten, sunt de neânlocuit în industria de producere a pastelor făinoase. Alături de calităţile pozitive posedă și particularităţi negative: este mai exigent la condițiile de producere, gradul de înfrățire este mai mic, rezistența la iernare este mai joasă și capacitatea de producție este mai inferioară grâului comun de toamnă. Acestea sunt cauzele principale a limitării arealului de răspândire a acestei culturi [1,2].

Pentru îmbunătățirea calităților culturii grâului durum, este necesar de a crea un genofond bogat, cu un spectru mai larg de variabilitate ereditară a tuturor caracterelor, studierea eredității caracterelor calitative și cantitative, mai ales a celor economic valoroase, în baza căreia vom trece la o selecție mai orientată [4].

Grâul durum de toamnă a apărut în rezultatul hibridării interspecifice, Triticum aestevum x Triticum durum. Această metodă, necătând la neajunsurile ce le are (instabilitatea citologică, sterilitatea hibrizilor $F_{1}$, letalitatea) prezintă o importanță deosebită pentru ameliorarea plantelor, pentru că dă posibilitatea utilizării fondului de gene, existent în special la formele spontane inrudite. Cu ajutorul hibridărilor îndepărtate, se pot ameliora mai ales rezistența la factorii nefavorabili: ger, secetă, boli, dăunători, adaptibilitatea la terenurile sărace, plasticitatea ecologică etc. [3, 5].

Metoda descrisă a avut prioritate în crearea grâului durum de toamnă, deoarece rezistența la ger este o însuşire genetică recisivă, ce se moștenește de la grâul comun de toamnă, manifestată de genele localizate în cromozomii 2B, 5A și 5D.

Având scopul de a crea forme noi de grâu durum de toamnă cu o rezistența înaltă la factorii abiotici și biotici am studiat hibrizii interspecifici, creați în urma hibridării celor mai bune soiuri și forme de grâu durum de toamnă cu soiurile omologate și de perspectivă de grâu comun de toamna.

\section{Materiale şi metode}

Ca material iniţial de cercetare ne-au servit soiurile și mostrele din colecția mondială a Institutului de Fitotehnie din Sanct-Petersburg și din alte instituții științifice, cât și formele create în Institutul de Genetică. În calitate de genitori s-au utilizat soiurile de grâu durum: Auriu 273, Chişinău 11, Hordeiforme 333, Hordeiforme 335, Hordeiforme 340, Cristall 2, Leucurum 2224 și altele, care se evidenţiază prin proprietăți valoroase ca, precocitate, talie joasă, înfrățire bună, rezistență la boli etc. Tot ca forme parentale au fost implimentate cele mai bune soiuri (omologate și de perspectivă) de grâu comun: Odesskaia 117, Vatra, Delfin, Moldova 11 și altele, care au un potențial de producție înalt și rezistență considerabilă la factorii nefavorabili ai mediului. Aprecierea rezistenței la iernare a plantelor s-a efectuat vizual, după raportul dintre numărul de plante ce s-a păstrat după îngheț și numărul de plante după germinație. Rezulta- 
tele testărilor, măsurărilor morfologice și a observărilor fenologice, au fost analizate matematic după Dospehov (1979).

\section{Rezultate și discuții}

Pentru crearea formelor noi de grâu durum de toamnă cu o rezistentă înaltă la iernare, secetă, cădere, boli și cu o productivitate sporită sa utilizat metoda de hibridare interspecifică.

Cercetările, realizate în domeniul selecției și geneticii grâului durum de toamnă ne-au arătat, că hibridarea îndepărtată este una din principalele metode de creare şi înbunătățire a acestei culturi.

În baza studierii materialului iniţial după caracterele valoroase au fost selectate cele mai bune soiuri după caracterele care ne interesează şi au fost utilizate în hibridări, ca forme parentale. Astfel în anii 2016 - 2019 au fost obținute 220 combinații hibride interspecifice. În rezultatul evaluării procentului de legare a hibrizilor $\mathrm{F}_{0}$ după cum vedem din diagramele 1 - 4 vedem, că rata de prindere a boabelor a fost foarte variată $(0-82,5 \%)$ şi depinde de tipul combinaţiei hibride, de condiţile mediului ambiant cât şi de compatibilitatea soiurilor utilizate ca forme parentale.
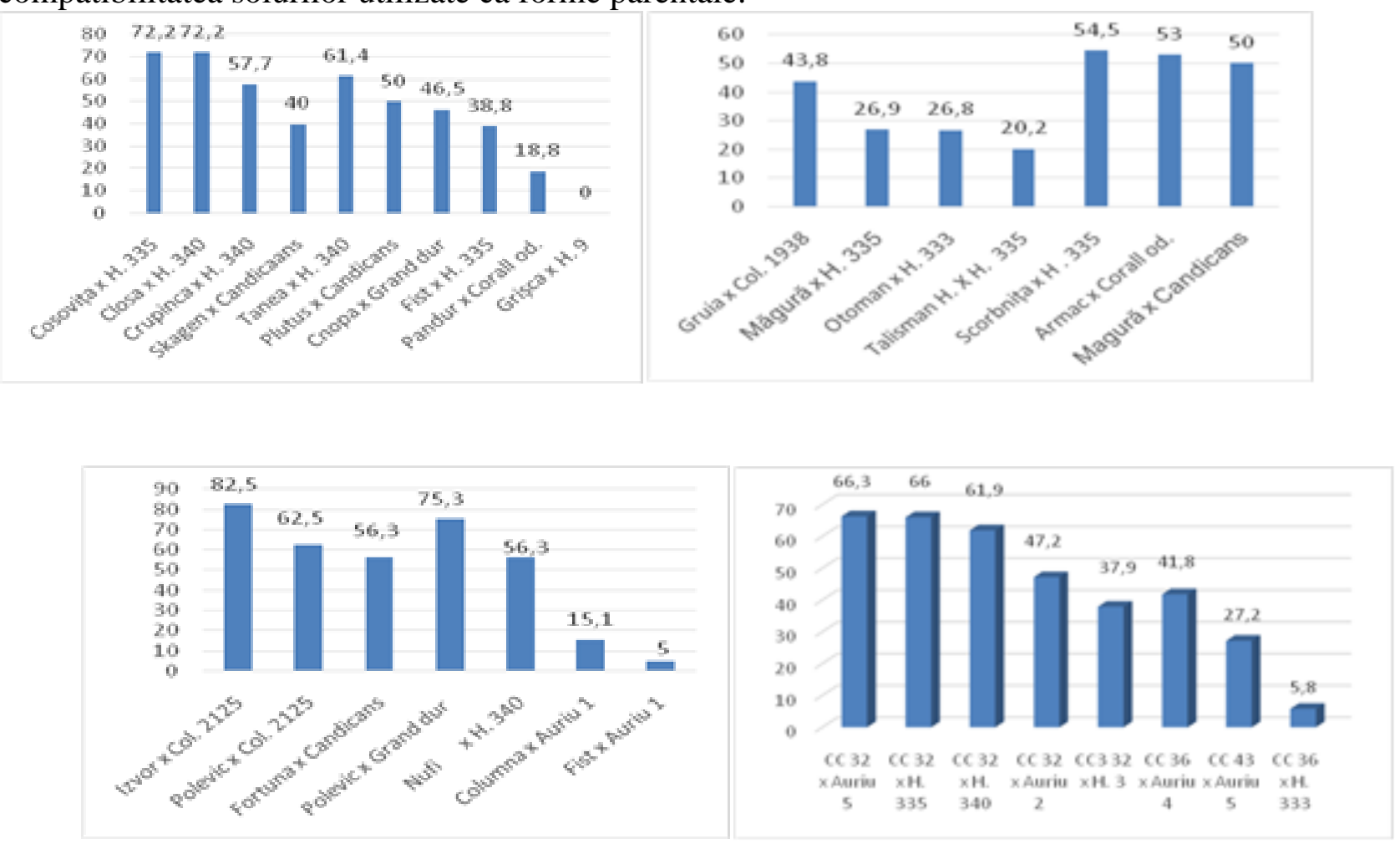

Fig.1, 2, 3, 4. Procentul de legare a boabelor la unele combinații hibride interspecifice de grâu durum de toamnă pe anii 2016-2019

În rezultatul apecierii vizuale a boabelor hibrizilor $\mathrm{F}_{0}$ timp de mai mulți ani am constatat că, în cazul când grâul dur e utilizat în încrucişări ca formă maternă, boabele sunt mai măşcate, dar sunt şistăvite, iar cănd grâul comun este utilizat ca formă maternă boabele sunt mai pline, dar de dimensiuni mai diminuate. Culoarea boabelor de asemenea se aseamănă mai mult la forma maternă. Prin urmare strucrura şi culoarea boabelor hibrizilor interspecifici este diferită în dependenţă de tipul de grâu utilizat ca formă maternă.

Procentul de germinaţie a boabelor a fost diferit în dependenţă de tipul hibridării. Cel mai mare procent de germinaţie s-a înregistrat la hibrizii intraspecifici şi a variat în limitele de 55,5-64,5\%. La hibrizii interspecifici a variat între 29,5-52,5\%. Prin urmare boabele hibrizilor interspecifici în comparaţie cu a celor intraspecifici au un procent de germinaţie mai mic. Acest fenomen se explică prin faptul că la hibrizii interspecifici e dereglat puternic procesul de meioză în rezultatul căruia se formează aneuploizi, care se elimină în diferite faze de dezvoltare.

Rezistenţa la iernare este mai mare la hibrizii $\mathrm{F}_{1}$ la care ca formă maternă am utilizat grâul comun şi anume soiurile Cosoviţa, Plutus, Scagen şi al. Genitorii au iernat comparativ bine, la grâul durum 8390\% şi comun $85-95 \%$.

La hibrizii interspecifici din prima generaţie dominanţa complectă se relevă numai după pubescenţa spicului şi lipsa aristelor. Culoarea spicului, aristelor, boabelor se moştenesc după tipul intermediar 
(tab.1). Avem și unele rezultate ale investigarii gradului de dominare a rezistenței la fuzarioza tulpinii a hibrizilor $F_{1}$. S-a concluzionat, că în majoritatea cazurilor rezistența la boală are un caracter dominant, însă gradul de dominare variază de la o formă la alta într-un diapazon larg de la nivelul intermediar până la supradominare. S-au constatat, atăt transgresii pozitive cât și negative determinate în cea mai mare parte nu de nivelul de sensibilitate a genitorilor ci de combinarea concretă a genelor în hibrizi.

Tabelul 1.Ereditarea caracterelor calitative la hibrizii interspecifici $\mathrm{F}_{1}$

\begin{tabular}{|l|l|l|l|l|l|l|}
\hline \multicolumn{1}{|c|}{$\begin{array}{c}\text { Combinaţia hibridă şi } \\
\text { genitorii }\end{array}$} & $\begin{array}{c}\text { Tipul } \\
\text { spicului }\end{array}$ & $\begin{array}{l}\text { Pubescent, } \\
\text { nepubescent }\end{array}$ & $\begin{array}{l}\text { Culoarea } \\
\text { spicului }\end{array}$ & $\begin{array}{l}\text { Culoarea } \\
\text { aristelor }\end{array}$ & $\begin{array}{l}\text { Culoarea } \\
\text { boabelor }\end{array}$ & $\begin{array}{l}\text { Densitatea } \\
\text { sp. }\end{array}$ \\
\hline Fist & aristat & nepubescent & alb & albe & roşii & 20,6 \\
\hline Fist x Auriu 273 & aristat & nepubescent & roz & roze & roze & 22,3 \\
\hline Auriu 273 & aristat & nepubescent & roşie & roşii & albe & 25,6 \\
\hline Cnopa & aristat & nepubescent & alb & albe & roşii & 20,2 \\
\hline Cnopa x Chişinău 11 & aristat & nepubescent & sur & sure & roze & 23,7 \\
\hline Chişinău 11 & aristat & nepubescent & negru & negre & albe & 25,4 \\
\hline Polevic & aristat & nepubescent & alb & albe & roşii & 19,8 \\
\hline Polevic x Mutico-leucurum & n/aristat & nepubescent & alb & albe & roze & 23,5 \\
\hline Mutico-leucurum & n/aristat & nepubescent & alb & albe & albe & 26,0 \\
\hline Iaşma & aristat & pubescent & alb & albe & albe & 26,8 \\
\hline Iaşma x Select & aristat & pubescent & roz & roze & roze & 24,0 \\
\hline Select & aristat & n/pubescent & roşu & roşii & roşii & 20,6 \\
\hline
\end{tabular}

În anii 2016-2019 s-a studiat heterozisul hibrizilor interspecifici. Cerceătrile efectuate asupra dezvoltării hibrizilor interspecifici au demonstrat, că în $\mathrm{F}_{1}$ se manifestă un heterozis somatic pronunţat în ceea ce priveşte înălţimea plantei, lungimea spicului şi numărului de spiculeţe (tab. 2).

Tabelul 2.Manifestarea heterozisului în procente la unii hibrizi interspecifici

\begin{tabular}{|c|c|c|c|c|c|c|c|c|c|c|}
\hline \multirow[t]{2}{*}{ Hibridul şi genitorii } & \multirow{2}{*}{$\begin{array}{c}\text { Înălț. } \\
\text { Plantei } \\
\text { cm }\end{array}$} & \multirow[t]{2}{*}{$\mathrm{H}^{*}$} & \multirow{2}{*}{$\begin{array}{c}\text { Lung. } \\
\text { sp. }\end{array}$} & \multirow[t]{2}{*}{$\mathrm{H}^{*}$} & \multicolumn{4}{|c|}{ Numărul de } & \multirow{2}{*}{$\begin{array}{c}\text { Masa } \\
\text { boa- } \\
\text { belor }\end{array}$} & \multirow[t]{2}{*}{$\mathrm{H}^{*}$} \\
\hline & & & & & $\frac{\frac{0}{0}}{\frac{0}{0}}$ & 盖 & $\begin{array}{l}0 \\
\text { ేี } \\
0\end{array}$ & 关 & & \\
\hline Scorbniţa & 92,4 & & 10,0 & & 20,6 & & 66,8 & & 1,60 & \\
\hline Scorbnița x Hord. 335 & 98,2 & 8,2 & 11,0 & 25,0 & 21,8 & 3,8 & 4,8 & 0,09 & 0,15 & 0,08 \\
\hline Hordeiforme 335 & 89,7 & & 7,6 & & 21,5 & & 41,7 & & 1,9 & \\
\hline Slujnița & 77,8 & & 9,8 & & 20,3 & & 47,4 & & 1.1 & \\
\hline Slujnița x Corall odesskii & 96,2 & 13,7 & 10,6 & 26,2 & 22,7 & 9,9 & 11,4 & 0,25 & 0,39 & 0,25 \\
\hline Corall odesskii & 91,4 & & 9,0 & & 21,0 & & 42,0 & & 2,0 & \\
\hline Clossa & 86,0 & & 10,5 & & 20,0 & & 62,9 & & 2,30 & \\
\hline Clossa x Cernomorca & 109,5 & 22,7 & 11,7 & 26,5 & 23.3 & 13,6 & 17,0 & 0,33 & 0,77 & 0,46 \\
\hline Cernomorca & 92,4 & & 8,0 & & 21,0 & & 38,5 & & 1,05 & \\
\hline Clossa & 86,0 & & 10,4 & & 19,0 & & 35,0 & & 0,98 & \\
\hline Clossa x Hordeiforme 333 & 93,4 & 6,3 & 10,7 & 18,8 & 22,2 & 9,7 & 28,2 & 0,73 & 0,72 & 0,68 \\
\hline Hord. 333 & 89,7 & & 7,6 & & 21,5 & & 41,7 & & 1,90 & \\
\hline Fist & 87,1 & & 10,2 & & 20,2 & & 44,6 & & 1,50 & \\
\hline Fist $\mathrm{x}$ Hord. 9 & 91,5 & 10,4 & 11,6 & 22,1 & 23,2 & 11,2 & 15,3 & 0,35 & 0,53 & 0,36 \\
\hline Hordiforme 9 & 78,7 & & 8,8 & & 21,5 & & 40,0 & & 1,48 & \\
\hline
\end{tabular}

$* \mathrm{H}$ - heterozisul hibrizilor.

În câmpul de hibrizi $\mathrm{F}_{2}$ sau studiat 62 hibrizi interspecifici. Germinaţia şi în deosebi supravieţuirea plantelor în perioada toamnă - iarnă s-a mărit. Cel mai bine au iernat hibrizii Zmina x H 333, Tanea x Auriu 273 şi altele. Segregarea s-a petrecut în plante de tip iniţial şi intermediar. A fost studiată împărţirea în plante de grâu comun ce a constituit 43,5 \% de tip dur -36,5 şi de tip intermediar $20 \%$.

În încheiere putem conchide, ca hibrizii interspecifici $F_{2}$ și descendenții ulteriori se caracterizează printr-un proces vigelios de segregare cu apariția grâului durum și aestivum cu indici agronomici înalți. 
Formele constante cu talia scurtă, cu spic și boabe mari de o sticlozitate înaltă, vor fi studiate în etapele următoare de selecție, cu scopul de a releva cele mai bune forme, după productivitate si rezistență la factorii stresanți de mediu.

\section{Concluzii}

- În anii 2016-2019 în rezultatul hibridărilor, interspecifice au fost obţinuti 220 hibrizi de grâu dur de toamnă cu un procent de prindere ce a variat în limitele de 0 - 82,5\%.

- La hibrizii interspecifici din prima generaţie dominanţa complectă se relevă numai după pubescenţa spicului şi lipsa aristelor. Culoarea spicului, aristelor, boabelor se moştenesc după tipul intermediar.

- Hibrizii interspecifici $F_{2}$ și descendenții ulteriori se caracterizează printr-un proces vigelios de segregare cu apariția grâului durum și aestivum cu indici agronomici valoroși.

Cercetările au fost realizate în cadrul proiectului Programului de Stat 20.80009.7007.04 „Biotehnologii și procedee genetice de evaluare, conservare și valorificare a agrobiodiversităţii”, finanţat de Agenţia Națională pentru Cercetare și Dezvoltare.

\section{Bibliografie}

1. CRISTEA, M. Clasic şi modern în ameliorarea plantelor. Bucureşti: Editura Academiei Române, 2006, 213 p.

2. RIZWAN, S., IFTIKHAR, A., ASHRAF, M. et al. New sources of wheat yellow rust (Puccinia striiformis f.sp. tritici) seedling resistance. In: Pak. J. Bot., 2007, 39, p. 595-602.

3. ROTARI, S. Obținerea şi studierea formelor noi de grâu durum de toamnă în Republica Moldova. În culegerea Agricultura durabilă în Republica Moldova: Provocări actuale şi perspective în culegeri de artticole ştiinţifice. Bălţi, 2017, p. 188-192.

4. SĂULESCU, N.N., ITTU, GH., GIURA, A. şi colab. Diversificarea bazei genetice ca fundament al progresului în ameliorarea grâului. In: Genetica şi ameliorarea plantelor, An. I.N.C.D.A. Fundulea. - Vol. LXXVIII, Nr. L, 2010, p .7-20.

5. САЛТЫКОВА, Н.Н. Роль межвидовой и межродовой гибридизации в эволюции мягкой и твердой озимой пшеницы и аграрные реформы в России опыт, проблемы перспективы. B: Материалы Рос. Научн. Проект. Конференции, Саратов., 22-24 сентября, 1994, с. 3-7. 